\title{
Ethical leadership and employee-organisational outcomes in the hotel industry
}

\author{
A. Tahernejad ${ }^{a *}$, Z. Seyed Ghorban ${ }^{b}$, R.N. Raja Ariffin ${ }^{c}$ and H. Babaei ${ }^{d}$ \\ ${ }^{\mathrm{a}}$ Faculty of Economics and Administration, University of Malaya (UM), Malaysia \\ ${ }^{b}$ Faculty of Business and Economics, Monash University, Australia \\ ${ }^{c}$ Faculty of Economics and Administration, University of Malaya (UM), Malaysia \\ ${ }^{\mathrm{d}}$ University of Tehran, Iran
}

*To whom all correspondence should be addressed

a.tahernejad@hotmail.com

\begin{abstract}
Ethical leadership has been attracting attention of different kinds. While the concept is still in its infancy, contribution from all aspects of business and management is required to examine the cross-sectional, cross-cultural applicability to provide further insights. Attempts have been made to theoretically and empirically examine the relationship between ethical leadership and several outcomes (e.g. job satisfaction, organisational commitment), however, most of these studies have been conducted in western countries. This calls for further analysis of this particular leadership style to fill the existing gap and enrich the literature. Using 183 samples from middle managers/supervisors in the hotel industry in Malaysia, the present study found that ethical leadership is positively and significantly related to both job satisfaction and organisational commitment among these middle managers, which then resulted in negative turnover and positive organisational citizenship behaviors amongst them. While, contributing significantly to the current literature on ethical leadership in the hospitality industry, this research also provides support for the notion of constructive consequences of leaders becoming role models in their organisations by following ethical standards in their behaviors and decisionmaking process.
\end{abstract}

\section{Introduction}

Ethics and ethical behaviours have been gaining extensive attention from both practitioners and researchers of different kinds due to the publicity of the current scandals and their negative impacts on business communities, industries, and many people (Verschoor, 2006, 2007). Recent ethical misconducts such as Enron, WorldComm, and Penn State University scandals (Jennings, 1999; Langvardt, 2012; McCraw, Moffeit, \& O'Malley, 2009; Russell \& Smith, 2003) imply the tremendous destructive effects of unethical behaviours on organisations and upon on people.

Leaders in organisations are the first to target if ethical misconducts are found (McCraw et al., 2009), since it is argued that they are to be largely blamed for any unethical incidents in organisations (Verschoor, 2007). To justify this reproach, it is believed that employees' adherence to ethical conduct is highly dependent on that of their managers and direct supervisors (Verschoor, 2007). On the other hand, becoming ethical role models in organisations enable leaders to promote ethical culture amongst their subordinates (Hunter, 2008). Thus, leaders need to act and behave ethically in their organisations as research indicates that the most successful organisations are those with ethical track record (Winston, 2007).

Brown, Treviño, and Harrison (2005) have pioneered in studying and conceptualising a distinct leadership style known as ethical leadership. This type of leadership, while being relatively new, has been gaining scholars' attentions (Gallagher \& Tschudin, 2010; Mayer, Kuenzi, Greenbaum, Bardes, \& Salvador, 2009; Stenmark \& Mumford, 2011) to investigate how it plays an influential role to improve organisational performance and therefore avoid any misconducts in the work environment. Lee and Cheng (2010) explored traits of leadership in improving managerial ethics in public relations and argued that there are 3 salient traits of an ideal leader as "personal ethics", "interpersonal behaviours", and "articulation of ethical standards". They believe that these traits can lead to knowledge transfer facilitation of ethics in public relation organisations. Others in similar ways argue that ethical leadership leads to perceived effectiveness of top managers and bring more optimism among employees with regard to the future of their organisation (De Hoogh \& Den Hartog, 2008).

Drawing from recent empirical investigations on ethical leadership and its relationship with different organisational outcomes such as job satisfaction, organisational commitment, and organisational citizenship behaviour (Mayer et al., 2009; Ruiz-Palomino, Ruiz-Amaya, \& Knörr, 2011; Walumbwa et al., 2011), an argument can be built in regard to its applicability and influential role in a different settings than those that have conducted so far, since leadership is believed to be a universal phenomenon and to translate across cultures (Bass, 1997). Few studies are available that have tried to establish cross-cultural 
applicability and generalisability of ethical leadership in a non-US and a non-western context, which provides further justification to conduct the current research.

Moreover, studies targeting ethical leadership in the hospitality industry are scarce (e.g. Kim \& Brymer, 2011) and an additional inquiry is required to enrich the relevant literature in this particular industry. It is important to study ethical leadership in different industrial settings as evidence indicates the substantial influence of unethical leadership or ethical misconduct on the future of any organisations (e.g. Langvardt, 2012). Consider the Penn State scandal, in which leaders' failure to take serious measured actions against villainous behaviour of a former but actively present employee led to a grave scandal (Langvardt, 2012). We believe that leaders are able to set very specific examples and behavioural models for their employees avoiding public shame and further financial and non-financial burdens resulting from it.

The main objective of this study is, therefore, to empirically examine ethical leadership in the hotel industry in a nonwestern country such as Malaysia to fill the existing gap, and to examine how becoming a role model boosts employee-organisational outcomes such as commitment, satisfaction, and citizenship behaviour in a different setting. This would also assist to establish the cross-cultural validity and applicability of ethical leadership. Malaysia is considered to be one of the most attractive tourist destinations in the world today. However, recent scandals in Malaysia such as the one concerning the bank officer arrested for credit cards forgery (The Star Online, 2012a), and the more recent scandal regarding the former credit manager of a hotel who has been sentenced to 12 years imprisonment for illegally transferring nearly 300,000 Malaysia Ringgit (equivalent to almost 100,000 USD) to her own credit card account from hotel guests (Tariq, 2012), also encourage one to study ethical leadership in this country to find out the overall gains. In this study, the main interest is to focus on middle level managers/supervisors to investigate what they think of their superiors in their respective organisations in terms of following ethical code of conducts in their behaviour and decision making process. The reason to choose middle level managers/supervisors is that they are more susceptible to understand what the top leaders do in the organisation, and their realisations of top leaders' ethical code of conducts would be more accurate due to their hierarchical proximity to the leaders.

\section{Background to the literature and hypotheses development}

Ethical leadership is defined as "the demonstration of normatively appropriate conduct through personal actions and interpersonal relationships, and the promotion of such conduct to followers through two-way communication, reinforcement, and decision-making" (Brown et al., 2005: 120). This definition comprises of four components as 1) followers and employees consider ethical leaders to present behaviours such as fairness, care, honesty, trustworthiness, etc. in which these leaders become role models for their subordinates; 2) ethics is the primary attention in the social environment and the ethical leaders provide voice for their followers, which is inferred as an interpersonally fairminded procedure (Bass \& Steidlmeier, 1999; Howell \& Avolio, 1992); 3) ethical standards are set by ethical leaders, ethical conducts would be rewarded and deviation of ethical conducts would be disciplined accordingly (Gini, 1998; Treviño, Brown, \& Hartman, 2003); and 4) ethical consequences of the decisions made by ethical leaders should be considered by those leaders in such a fair and principled way that could be imitated and observed by others (Burns, 1978; Howell \& Avolio, 1992).

Studying what Brown, et al. (2005) have conceptualised as ethical leadership style has been attracting scholars' attention (e.g. Martin, Resick, Keating, \& Dickson, 2009; Walumbwa et al., 2011). Similar to other leadership styles, different aspects of this particular type of leadership need to be investigated to find out how and to what extent it benefits people and organisations. There are various studies that have investigated the concept of ethical leadership and the related issues in the domain of general management (Brown \& Treviño, 2006; Brown et al., 2005; Cullen, Parboteeah, \& Victor, 2003; Neubert, Carlson, Kacmar, Roberts, \& Chonko, 2009; Treviño, Brown, \& Hartman, 2003); however, Brown and Trevino (2006) specifically argued that ethical leadership impacts several organisational outcomes such as follower ethical decision making, follower satisfaction, commitment, and their engagement to put in extra effort. Subsequent examinations have provided support for this notion, and suggest that ethical leadership is directly and indirectly related to followers' job satisfaction and organisational commitment (e.g. Kim \& Brymer, 2011; Neubert et al., 2009), their lower turnover intention (e.g. Kim \& Brymer, 2011) and higher organisational citizenship behaviour (e.g. Ruiz-Palomino et al., 2011).

The existing arguments indicate the significant role of ethical codes in different hospitality sectors (Coughlan, 2001; Kincaid, Baloglu, \& Corsun, 2008; Stevens, 1997); nonetheless studying ethical leadership as Brown et al. (2005) have conceptualised would not only enrich the literature in the domain of general management, but would also provide further insights in the hospitality industry point of view.

Job satisfaction is defined as "a pleasurable or positive emotional stable resulting from the appraisal of one's job as achieving or facilitating one's job value. (Locke, 1969: 316). Its positive relationship with ethical leadership has been postulated (Brown \& Treviño, 2006; Brown et al., 2005) and further examinations have also provided empirical evidence supporting this relationship in other industries (e.g. Neubert et al., 2009). As previously explained, leaders who discipline wrongdoings and treat their followers fairly, would considerably enhance job satisfaction among their followers (Brown et al., 2005). Referring to the above postulation and empirical supports, same logical inference can be drawn for the positive relationship between ethical leadership and employee job 
satisfaction in the hotel industry as one major sector of the hospitality industry in Malaysia. We, therefore, propose the following hypothesis:

Hypothesis 1: Ethical leadership of top managers is positively related to middle level managers' job satisfaction.

Leadership-commitment link have long been investigated and the findings suggest the relationship between leadership and commitment is positive and significant (e.g. Barling, Weber, \& Kelloway, 1996; Bycio, Hackett, \& Allen, 1995; Podsakoff, Todor, Grover, \& Huber, 1984). Ethical leadership can impact organisational commitment in a similar way as ethical leaders are committed to particular code of conducts in their behaviours and could be influential on their subordinates' behaviours such as enhancing their level of affective commitment. Allen and Meyer (1990) defined three constructs for organisational commitment as "affective", "continuance", and "normative" commitment. Affective commitment is regarded as the most widespread form of organisational commitment (Allen \& Meyer, 1990; Meyer \& Allen, 1987) and considered as one being emotionally and effectively attached to his/her organisation and identifies him/herself with it while enjoying the membership in the organisation (Meyer \& Allen, 1997; Meyer, Allen, \& Smith, 1993).

The argument regarding the positive and significant relationship between ethical leadership and organisational commitment is supported by what Brown and Treviño (2006) posited as the direct relationship of ethical leadership with followers' organisational commitment and by the empirical evidence that supports this relationship (Kim \& Brymer, 2011; Neubert et al., 2009). Drawing from the above discussion we, then, hypothesise that:

Hypothesis 2: Ethical leadership of top managers is positively related to middle level managers' organisational commitment.

The prior research support the positive relationship between job satisfaction and affective organisational commitment (e.g. Mathieu \& Zajac, 1990), and the causal relationship has been established in different literatures (Fletcher \& Williams, 1996; Yang, 2010). Findings also support that employees with greater job satisfaction tend to have higher affective commitment in hospitality industry (Kim \& Brymer, 2011; Kim, Leong, \& Lee, 2005). Based on the previous results, we propose that:

Hypothesis 3: Middle level managers' job satisfaction is positively related to their affective commitment.

Both job satisfaction and affective commitment have been demonstrated to have negative relationship with turnover intention. Job satisfaction is considered as an important predictor of turnover intention (Williams \& Hazer, 1986) and employees with higher job satisfaction tend to have lower intention to leave their organisations (Chen, 2006; Eugenia, Sanz Valle, \& Aragón, 2007; Schwepker Jr, 2001).
On the other hand, the negative relationship between organisational commitment and turnover intention has been substantiated in several literature; and empirical research also provide support for the notion that employees' higher affective commitment leads to their lower intention to leave their organisations (Colbert \& Kwon, 2000; Kim \& Brymer, 2011; Schwepker Jr, 2001).

Based on the above discussions, we propose the following hypotheses:

Hypothesis 4: Middle level managers' job satisfaction is negatively related to their turnover intention.

Hypothesis 5: Middle level managers' affective commitment is negatively related to their turnover intention.

Organisational citizenship behaviour is explained as an important phenomenon in the work environment to enhance employee's social and psychological attachment to their organisations (Podsakoff, MacKenzie, Paine, \& Bachrach, 2000; Ruiz-Palomino et al., 2011). Brown, et al. (2005) postulated that ethical leadership could improve subordinates' extra efforts in organisations. Helping behaviour, sharing new ideas, being extra involved for the success of the organisations (as different aspects of citizenship behaviours) are all mentioned as the examples of what Brown, et al. (2005) posited as extra efforts (RuizPalomino et al., 2011).

While attempts have been made to relate ethical leadership to organisational citizenship behaviour (Mayer et al., 2009), both job satisfaction and organisational commitment have been empirically shown to be important antecedents of organisational citizenship behaviour (e.g. LePine, Erez, \& Johnson, 2002; Podsakoff et al., 2000). Empirical findings suggest that employees with higher level of job satisfaction and commitment would engage actively in their organisations (Ruiz-Palomino et al., 2011). Organisational citizenship behaviour has also been shown to be the consequence of both job satisfaction and organisational commitment (e.g. Hackett, Farh, Song, \& Lapierre, 2003). Accordingly, we hypothesise the following:

Hypothesis 6: Middle level managers' job satisfaction is positively related to their organisational citizenship behaviour.

Hypothesis 7: Middle level managers' affective commitment is positively related to their organisational citizenship behaviour. 


\section{Methodology}

\section{Sample}

To obtain the desired samples for the purpose of the current study middle level managers in the hotel industry in the city of Kuala Lumpur were requested to participate. This study tried to include all levels of middle managers in this particular industry ranging from general managers to purchasing managers. The zones with hotel density within the same area were identified to collect the data. These areas include, but not limited to, City Centre, Golden Triangle, Bukit Bintang, PWTC, and comprise all kinds of hotels (budget to luxury) to be a representative and generalisable sample.

Since this study focused on studying middle level managers/supervisors in the hotel industry, collecting the data would seem difficult to begin with, however arrangements were made to engage in data collection procedure. First, the necessary documentations were presented when the first contacts were made to clarify the purpose of the visit. In almost every case, the hotel concierges were approached for this purpose. They were explained the nature and purpose of the research and asked to make appointments with the people in charge, whereby in the majority of the cases, it was the general managers. After further clarifications were made regarding the objectives of the study for those managers who agreed to participate in the study, three to five copies of the questionnaires were presented to them to be collected later at the arranged time.
The contact managers were requested to answer one of the questionnaires and give the rest to their co-workers, who were holding managerial positions of the same levels. The managers were ensured that the information provided would be kept confidential and used for research purpose only. They were also asked not to provide any personal information whatsoever to ensure the anonymity of their responses.

After visiting different hotels in different areas of Kuala Lumpur and distributing almost 300 questionnaires among the middle managers/supervisors, we received 197 completed questionnaires $(66 \%)$. As the contact person was requested to distribute the rest of the questionnaires among his/her co-workers in the same levels, in 24 cases only one manager in a hotel filled the questionnaire representing 24 hotels. In the rest of the cases, we received at least 2 completed questionnaires from each hotel. We discarded 14 questionnaires due to incomplete and inconsistent information provided, and included 183 valid responses in the data analysis. The number of data received is believed to be enough and appropriate for both factor analysis and hypotheses testing. Based on the 20:1 subject-to-variables ratio proposed by Hair, et al. (2010), this study by far exceeded the number of samples required to conduct factor analysis and hypotheses testing.

The first part of the questionnaires developed for the current study enquired the demographic information of the participants and is presented in table 1 .

Table 1: Descriptive statistics

\begin{tabular}{|c|c|c|c|c|c|}
\hline Variable & Frequency & $\%$ of total & Variable & Frequency & $\%$ of total \\
\hline Gender & & & Education & & \\
\hline Male & 139 & 76.0 & Some college & 29 & 15.8 \\
\hline Female & 44 & 24.0 & Bachelor & 140 & 76.5 \\
\hline Age & & & Master & 14 & 7.7 \\
\hline $20-30$ & 3 & 1.6 & Experience & & \\
\hline $31-40$ & 71 & 38.8 & $1-10$ years & 52 & 28.4 \\
\hline $41-50$ & 97 & 53.0 & $11-20$ years & 89 & 48.6 \\
\hline \multirow[t]{2}{*}{$>50$} & 12 & 6.6 & $21-30$ years & 37 & 20.2 \\
\hline & & & $>30$ & 5 & 2.7 \\
\hline
\end{tabular}

\section{Instrumentation}

The second part of the questionnaire developed for this research included the total number of 29 questions. Ten items adopted from Brown, et al. (2005) to measure ethical leadership. To measure affective commitment, eight items developed by Meyer and Allen (1991) was used. Job satisfaction was measured using four items developed by Babakus et al. (2003). Three items were adopted from Karatepe and Uludag (2008) to measure turnover intention. Organisational citizenship behaviour was measured using four items adopted from Cardona, Lawrence, and Bentler (2004).

\section{Results}

\section{Reliability and validity}

Using Cronbach's Alpha reliability test, all instruments appeared to be accurate in what they measured ( $\alpha$ ranging from .91 to .95). Construct validity was subsequently conducted using factor analysis, convergent validity, and discriminant validity. First, exploratory factor analysis (EFA) was conducted with principal component analysis developed by Hotteling (1935) and Varimax rotation method (Kaiser, 1958) on all the variables to determine the number of factors. The conditions for this analysis were based on what Kaiser (1958) suggested: "an Eigen value greater than one and an absolute value of factor loading larger than 0.50 ". The analysis of all 29 items resulted in 5 components 
extraction with Eigen values greater than one. All factor loadings were above 0.50 , meeting the criteria proposed by Kaiser (1958) in conducting factor analysis. Table 2 presents the findings from the exploratory factor analysis.

Table 2: Exploratory factor analysis

\begin{tabular}{ccccc}
\hline Factor & Initial & \multicolumn{3}{c}{ Rotation sums of squared loadings } \\
\cline { 3 - 5 } & $\begin{array}{c}\text { Eigen } \\
\text { values }\end{array}$ & Total & $\begin{array}{c}\text { Percentage of } \\
\text { variance }\end{array}$ & $\begin{array}{c}\text { Cumulative } \\
\text { percentage }\end{array}$ \\
\hline 1 & 17.132 & 6.866 & 23.675 & 23.675 \\
2 & 1.740 & 5.837 & 20.126 & 43.801 \\
3 & 1.215 & 3.510 & 12.105 & 55.906 \\
4 & 1.137 & 3.364 & 11.537 & 67.443 \\
5 & 1.034 & 2.699 & 9.307 & 76.750 \\
\hline
\end{tabular}

Note: $\mathrm{N}=183$. Method: Principal Component Analysis with Varimax rotation

Confirmatory factor analysis (CFA) was performed using AMOS 18.0 with maximum likelihood estimation (Arbuckle, 2009). The results shown in table 3 established the construct validity. All loadings surpassed 0.60 and all tvalues exceeded the accepted level of 1.96 (Arbuckle, 2009). All average variance extracted (AVE) were above 0.50 and all composite reliability (CR) exceed 0.70 (Hair et al., 2010). Maximum shared squared variance (MSV) and average shared squared variance (ASV) should both be less than average variance extracted (AVE) to establish the discriminant validity (Hair et al., 2010).

Table 3: Description statistics of CFA analysis

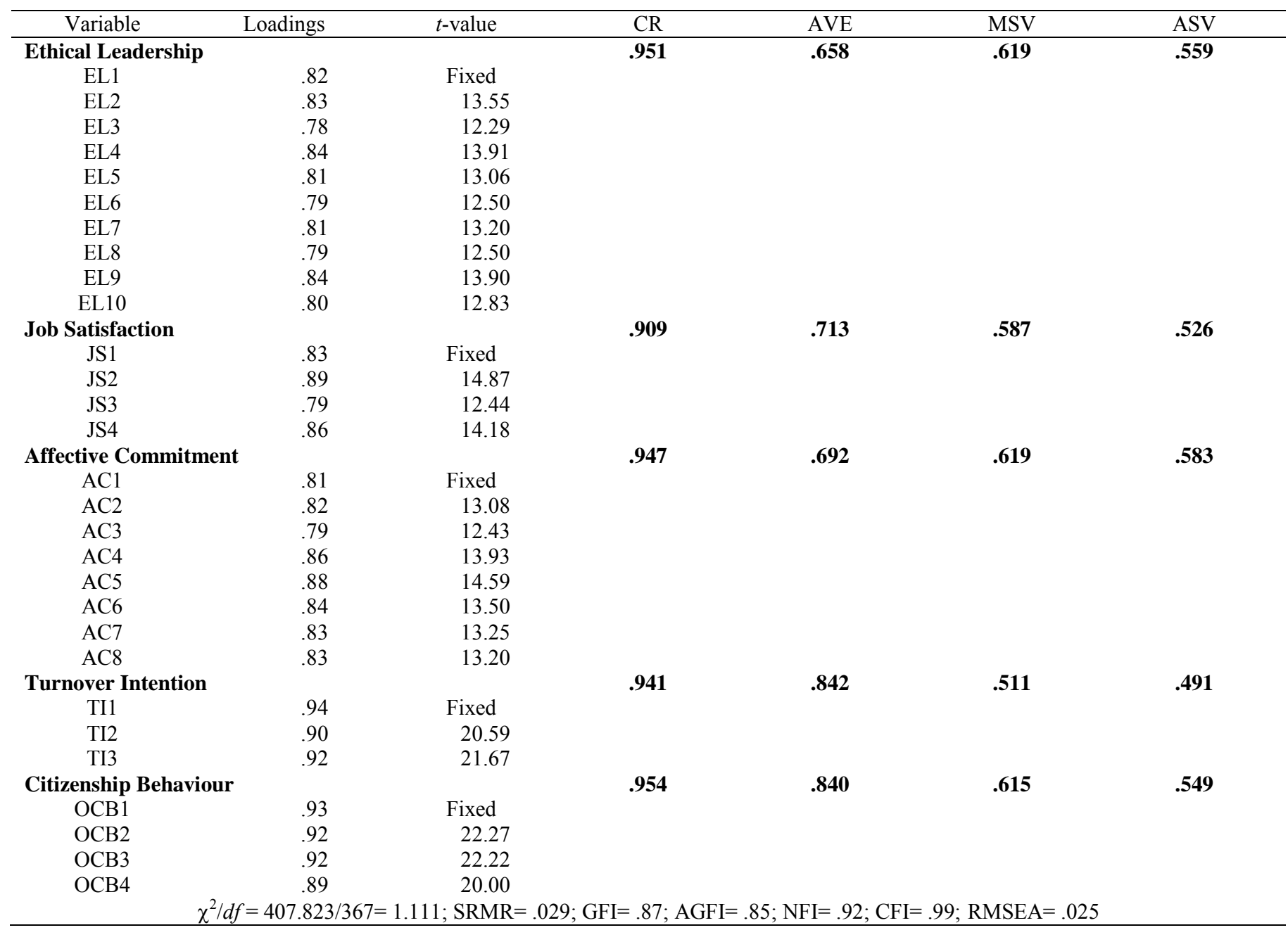

Since this study collected the data from one single source, there might be concerns regarding the common method bias. Common method bias is believed to be insignificant in this study, since a large percentage of the variance could not be explained by one single general factor (Podsakoff, MacKenzie, Lee, \& Podsakoff, 2003).

\section{Structural Model}

Structural equation modelling using AMOS 18.0 with maximum likelihood estimation (Arbuckle, 2009) was developed for hypotheses testing and the results obtained are shown in the table 4. 
Table 4: SEM paths results for the proposed hypotheses

\begin{tabular}{|c|c|c|c|c|}
\hline \multicolumn{2}{|r|}{ Hypotheses } & \multirow{2}{*}{$\frac{\text { Standardised coefficient }}{.75^{* * *}}$} & \multirow{2}{*}{$\frac{\text { t-value }}{9.71}$} & \multirow{2}{*}{$\begin{array}{c}\text { Conclusion } \\
\text { Supported }\end{array}$} \\
\hline $\mathrm{H} 1$ & Ethical Leadership $\rightarrow$ Job Satisfaction & & & \\
\hline $\mathrm{H} 2$ & Ethical Leadership $\rightarrow$ Affective Commitment & $.51 * * *$ & 6.07 & Supported \\
\hline H3 & Job Satisfaction $\rightarrow$ Affective Commitment & $.38 * * *$ & 4.65 & Supported \\
\hline H4 & Job Satisfaction $\rightarrow$ Turnover Intention & $-.31 * * *$ & -3.30 & Supported \\
\hline H5 & Affective Commitment $\rightarrow$ Turnover Intention & $-.49 * * *$ & -5.06 & Supported \\
\hline H6 & Job Satisfaction $\rightarrow$ Citizenship Behaviour & $.31 * * *$ & 3.64 & Supported \\
\hline $\mathrm{H} 7$ & Affective Commitment $\rightarrow$ Citizenship Behaviour & $.56^{* * *}$ & 6.32 & Supported \\
\hline Model Fit & \multicolumn{4}{|c|}{$\chi^{2} / d f=431.791 / 370=1.167 ; \mathrm{SRMR}=.039 \mathrm{GFI}=.87 ; \mathrm{AGFI}=.85 ; \mathrm{NFI}=.92 ; \mathrm{CFI}=.99 ; \mathrm{RMSEA}=.030$} \\
\hline
\end{tabular}

Ethical leadership found to be positively related to both job satisfaction and affective organisational commitment supporting hypotheses one and two. Findings indicated that job satisfaction was positively and significantly related to affective organisational commitment, supporting hypothesis three. Both job satisfaction and affective organisational commitment were negatively related to turnover intention providing support for hypotheses four and five. With regard to hypotheses six and seven, both job satisfaction and affective organisational commitment were found to be positively and significantly related to organisational citizenship behaviour.

\section{Conclusions and implications}

This study set out to address the issue of ethical leadership in a context different from those previously investigated. The current study empirically investigated the concept of ethical leadership in the hospitality industry focusing on middle level managers/supervisors in different hotels in Malaysia. Consequently, this research focused to investigate how ethical leadership could enhance both employee level outcomes (satisfaction and commitment) and organisational level outcomes (turnover intention and citizenship behaviours). This contribution of attending to both levels of outcomes makes this study a unique one in expanding both theoretical and practical knowledge of studying ethical leadership in the hospitality industries.

Brown, et al. (2005) argued that ethical leadership is associated positively with satisfaction with leader and with job dedication. Furthermore, these relationships have been empirically examined (e.g. Neubert et al., 2009), and arguments regarding ethical leadership being a significant driver of both employee satisfaction and commitment have been supported (e.g. Ruiz-Palomino et al., 2011). The outcomes from the current study not only conform to the results of prior research but also extend the ethical leadership applicability in the hospitality industry in a nonwestern society that are consistent with the previous findings. Results obtained from this research suggest the positive and significant relationship of ethical leadership with both job satisfaction and affective commitment.

Brown and Trevino (2006) proposed that ethical leaders are considered to be role models in complying with particular ethical code of conducts, which would subsequently lead to employees expressing positive behaviours toward their organisations by being more satisfied and committed (Kim \& Brymer, 2011; Neubert et al., 2009; Ruiz-Palomino et al., 2011). Findings, whilst support this notion, suggest that being a role model is not limited to a particular industry or sector and could be generalised to other kinds of organisations. Inferring from those results, it could be argued that leaders are able to foster the sense of satisfaction and commitment among their employees by becoming role models in their organisations.

Furthermore, based on the definitions provided for job satisfaction (Locke, 1969) and affective commitment (Meyer \& Allen, 1997), it could be argued that the possibility of satisfied and committed employees engaging in unethical incidences would be far less than those who are not. What these employees do is satisfying and enjoying, and they are eager to stay and become committed to their organisation because they want to. This sense of pleasure and desire to stay amongst employees is deep rooted in what they observe as a role model in their organisations, who "talks the talk" and "walks the walk" in terms of being ethically committed to the objective of the organisations. This role model makes and clarifies the ethical journey of the organisation by establishing the necessary standards. $\mathrm{He} / \mathrm{she}$ is a pioneer in expressing ethical behaviours and conducting ethical decision-makings, which would lead to satisfied and committed employees. These role models, while being targeted for any misconduct in organisations, should also be credited with any successful ethical journey because they make this happen and bring prosperity.

Findings from the current research indicate that the level of satisfaction and commitment among middle managers/supervisors in the hospitality industry would be influenced by the way their superiors behave. Superiors by being ethical role models (being honest, fair, and considerate) in this particular industry and treat their subordinates in a fair manner are believed to significantly impact employees' behavioural outcomes toward their organisations. These findings are consistent with what Brown and Trevino (2006) postulated regarding the ability of ethical leadership to influence different organisational outcomes among employees.

In addition, the relationship between job satisfaction and organisational commitment has been addressed and empirical results suggest that job satisfaction is positively related to organisational commitment (Fletcher \& Williams, 
1996; Mathieu \& Zajac, 1990; Yang, 2010). Consistent with prior research, the findings from this study demonstrated that middle managers'/supervisors' job satisfaction is positively related to their affective commitment. When they feel satisfied and pleased with their working environments and with what they do, they would become committed and willingly stay in their organisations.

Another important part of our findings is the inclusion turnover intention and organisational citizenship behaviour as organisational outcomes resulted from satisfied and committed employees. Brown and Trevino (2006) argued that social exchange relationship would require employees to engage in a mutual fair and caring treatment when they are treated in a fair manner; and consequently they would express less counterproductive behaviours such as turnover intention. Turnover intention among subordinates has been a major concern for leaders in the hotel industry, since it will lead to increase in the associated costs such as hiring and training (Dalton \& Todor, 1982). Findings from this study indicate that greater job satisfaction and commitment lead to lower turnover intention among middle level managers. While consistent with previous results, this would support the notion that being treated fairly and considerately would drive the sense of satisfaction and commitment, which consequently result in less counterproductive behaviours such intention to leave the organisation.

Moreover, the findings obtained suggest that both job satisfaction and organisational commitment are positively and significantly related to employee organisational citizenship behaviour. Prior studies have provided support for the significant role of both job satisfaction and organisational commitment in enhancing organisational citizenship behaviour (Hackett et al., 2003). In the context of ethical leadership, the present study provides further insights for the key role that satisfaction and commitment play in improving citizenship behaviour among middle managers in the hospitality industry. This research implies that satisfied and committed employees would express more citizenship behaviours by sharing ideas, putting extra efforts and displaying helping behaviours for the benefit of their organisations.

This research focused on investigating ethical leadership in the hotel industry in a setting different from those previously examined. The hotel industry in a country like Malaysia, which has been reported by the United Nations World Tourism Organisation (UNWTO) to be in the list of 10 most visited countries in the year 2010 (The Star Online, 2012b), was an appropriate target, since evidences of some unethical incidences also provided justification for the investigation. Empirical results drawn from Malaysian samples provide support for the influence of the ethical leadership on satisfaction and commitment, which then impact turnover intention negatively and citizenship behaviour positively. This would imply that hotel industry leaders in Malaysia would be able to avoid any ethical deviations by expressing ethical leadership characteristics, and by becoming role models in their behaviours and decision-making process.
The managerial implication for the current investigation into the hotel industry is threefold. Findings of this study provide important managerial insights in which becoming a role model (treat others in a fair, honest, and considerate manner) and establishing standards in conducting ethical codes of conduct would result in greater productivity among subordinates' behaviours toward their organisations. Managers should be aware that ethical leadership could enhance both employee level outcomes and organisational level outcomes. First, in terms of employee level outcomes, managers are able to enhance two very important factors in this level, namely job satisfaction and affective commitment. Employees would be more satisfied and committed to their work if they witnessed the presence of a role model in their organisation that not only determines ethical standards but also abides and adheres to those standards in his/her behaviours and decision-making procedures.

Second, in terms of organisational level outcomes, managers should consider the findings from this study that organisational level outcomes such as turnover intentions and organisational citizenship behaviours could be significantly enhanced when employees are satisfied and committed. Turnover intention is a major concern for leaders in the hotel industry and it would increase the associated costs relevant to hiring and training (Dalton \& Todor, 1982). Managers could avoid such costs by making employees satisfied and committed, which would result in decreasing their intention to leave the organisation and create the climate of extra efforts (sharing ideas, helping behaviours, etc.) for the success of the organisations. On the other hand, retaining the current employees (by making them satisfied and committed) would be more economical than hiring new ones. New employees might not be as attached to the organisations as those current employees, which would seriously undermine organisations' efficiency.

Third, managers in the hospitality industry are able to hinder ethical deviances in their employees' behaviour by becoming role models in their organisations that would promote ethical culture among their subordinates (Hunter, 2008). Such deviances from the ethical code of conduct would ultimately destruct the organisations' reputation and performance and would lead to both financial and nonfinancial difficulties. Scandals such as Enron should be considered a warning sign for organisations to realise that unethical behaviours could not be tolerated anymore in the world today, and people would extremely react to these notorieties. Likewise, the hospitality industry could be equally damaged and face various drastic consequences if an unethical behaviour is found and reported to the public.

This study only focused on middle level managers/supervisors in the hotel industry. Unlike ordinary employees, middle level managers are in more contact with their own managers and they are more susceptible to grasp what their managers do and how they behave. They could engage and exchange relationships with their leaders more quickly, which would enable the organisation to rapidly expand the role model of the leaders in following ethical 
codes of conduct in their behaviour and their decision making. Future studies could investigate employees and staffs beside middle level managers, since ordinary employees in this particular industry could also play important roles due to their high customer contact. Future studies can also examine how ethical leadership effects financial performance such as sales and profitability and non-financial performance such as firm reputation by adding those variables to the current model. The current model could also be studied in other sectors of hospitality or in other industries, as this study could only target one sector in hospitality industry.

\section{Reference}

Allen, \& Meyer. 1990. 'The measurement and antecedents of affective, continuance and normative commitment to the organisation', Journal of Occupational Psychology, 63(1):1-18.

Arbuckle, J.L. 2009. Amos 18 User's Guide. Chicago, IL: SPSS Inc.

Babakus, E., Yavas, U., Karatepe, O.M. \& Avci, T. 2003. 'The effect of management commitment to service quality on employees' affective and performance outcomes', Journal of the Academy of Marketing Science, 31(3):272-286.

Barling, J., Weber, J. \& Kelloway, E.K. 1996. 'Effects of transformational leadership training on attitudinal and financial outcomes: A field experiment', Journal of Applied Psychology, 81(6):827-832.

Bass, B.M. 1997. 'Does the transactional-transformational leadership paradigm transcend organisational and national boundaries?', American Psychologist, 52(2):130-139.

Bass, B.M. \& Steidlmeier, P. 1999. 'Ethics, character, and authentic transformational leadership behavior', Leadership Quarterly, 10(2):181-218.

Brown, M.E. \& Treviño, L.K. 2006. 'Ethical leadership: A review and future directions', The Leadership Quarterly, 17(6):595-616.

Brown, M.E., Treviño, L.K., \& Harrison, D.A. 2005. 'Ethical leadership: A social learning perspective for construct development and testing, Organisational Behavior and Human Decision Processes, 97(2):117-134.

Burns, J.M. 1978. Leadership. New York: USA: Harper \& Row.

Bycio, P., Hackett, R.D. \& Allen, J.S. 1995.' Further assessments of Bass's (1985) conceptualisation of transactional and transformational leadership', Journal of Applied Psychology, 80(4):468-478.

Cardona, P., Lawrence, B.S. \& Bentler, P.M. 2004. 'The influence of social and work exchange relationships on organisational citizenship behaviour', Group \& Organisation Management, 29(2):219-247.

Chen, C.-F. 2006. 'Job satisfaction, organisational commitment, and flight attendants, turnover intentions: A note', Journal of Air Transport Management, 12(5):274-276.
Colbert, A.E. \& Kwon, I.G. 2000. 'Factors related to the organisational commitment of college and university auditors', Journal of Management Issues, 11(4):484-502.

Coughlan, R. 2001. 'An analysis of professional codes of ethics in the hospitality industry', International Journal of Hospitality Management, 20(2):147-162.

Cullen, J., Parboteeah, K. \& Victor, B. 2003. 'The effects of ethical climates on organisational commitment: A two-study analysis', Journal of Business Ethics, 46(2):127-141.

Dalton, D.R. \& Todor, W.D. 1982. 'Turnover: A lucrative hard dollar phenomenon', Academy of Management Review, 7(2):212218.

De Hoogh, A.H.B. \& Den Hartog, D.N. 2008. 'Ethical and despotic leadership, relationships with leader's social responsibility, top management team effectiveness and subordinates' optimism: A multi-method study', The Leadership Quarterly, 19(3):297-311.

Eugenia, S.V.M., Sanz Valle, R. \& Aragón, I. B. M. 2007. 'Antecedents of repatriates' job satisfaction and its influence on turnover intentions: Evidence from Spanish repatriated managers', Journal of Business Research, 60(12):1272-1281.

Fletcher, C. \& Williams, R. 1996. 'Performance management, job satisfaction and organisational commitment', British Journal of Management, 7(2):169-179.

Gallagher, A. \& Tschudin, V. 2010. 'Educating for ethical leadership', Nurse Education Today, 30(3):224-227.

Gini, A. 1998. 'Moral leadership and business ethics', In J.B. Ciulla (Ed.), Ethics, the heart of leadership (pp. 27-45). Westport, CT: Quorum Books.

Hackett, R.D., Farh, J., Song, L.J. \& Lapierre, L.M. 2003. 'LMX and organisational citizenship behavior: Examining the links within and across Western and Chinese samples', In G. B. Graen (Ed.), Dealing with diversity (A volume in LMX leadership: The series) (pp. 219-264). Greenwich: CT: Information Age.

Hair, J., Black, W., Babin, B. \& Anderson, R. 2010. Multivariate data analysis (7th ed.). Upper Saddle River, NJ: Prentice Hall, Inc.

Hotteling, H. 1935. 'The most predictable criterion', Journal of Educational Psychology, 26(2):139-142.

Howell, J.M. \& Avolio, B.J. 1992. 'The ethics of charismatic leadership: Submission or liberation', Academy of Management Executive, 6(2):43-54.

Hunter, S. 2008. 'Ethics: The framework for success', Strategic Finance, 89(10):51-53.

Jennings, M.M. 1999. 'What's happening in business schools?', The Public Interest, 137:25-32.

Kaiser, H. 1958. 'The varimax criterion for analytic rotation in factor analysis', Psychometrika, 23(3):187-200.

Karatepe, O.M. \& Uludag, O. 2008. 'Affectivity, conflicts in the work, family interface, and hotel employee outcomes', International Journal of Hospitality Management, 27(1):30-41. 
Kim, W.G. \& Brymer, R.A. 2011. 'The effects of ethical leadership on manager job satisfaction, commitment, behavioral outcomes, and firm performance', International Journal of Hospitality Management, 30(4):1020-1026.

Kim, W.G., Leong, J.K. \& Lee, Y.K. 2005. 'Effect of service orientation on job satisfaction, organisational commitment, and intention of leaving in a casual dining chain restaurant', International Journal of Hospitality Management, 24(2):171-193.

Kincaid, C.S., Baloglu, S. \& Corsun, D. 2008. 'Modeling ethics: The impact of manage- ment actions on restaurant workers' ethical optimism', International Journal of Hospitality Management, 27(3):470-477.

Langvardt, A.W. 2012. 'Ethical leadership and the dual roles of examples', Business Horizons, 55(4):373-384.

Lee, S.T. \& Cheng, I.H. 2010. 'Characteristics and dimensions of ethical leadership in public relations', Journal of Public Relations Research, 23(1):46-74

LePine, J.A., Erez, A. \& Johnson, D.E. 2002. 'The nature and dimensionality of organisational citizenship behaviour: A critical review and meta-analysis', Journal of Applied Psychology, 87(1):52-65.

Locke, E.A. 1969. 'What is job satisfaction?', Organisational Behavior and Human Performance, 4(4):309-336.

Martin, G.S., Resick, C.J., Keating, M.A. \& Dickson, M.W. 2009 'Ethical leadership across cultures: A comparative analysis of German and US perspectives', Business Ethics: A European Review, 18(2):127-144.

Mathieu, J.E. \& Zajac, D.M. 1990. 'A review and meta-analysis of the antecedents, correlates, and consequences of organisational commitment', Psychological Bulletin, 108(2):171-194.

Mayer, D.M., Kuenzi, M., Greenbaum, R., Bardes, M. \& Salvador, R. 2009. 'How low does ethical leadership flow? Test of a trickledown model', Organisational Behavior and Human Decision Processes, 108(1):1-13.

McCraw, H., Moffeit, K.S. \& O'Malley, J.R. 2009. 'An analysis of the ethical codes of corporations and business schools', Journal of Business Ethics, 87(1):1-13.

Meyer, J.P. \& Allen, N.J. 1987. 'Organisational commitment: Toward a three-component model', Research Bulletin, The University of Western Ontario, Department of Psychology, London, 660.

Meyer, J.P. \& Allen, N.J. 1991. 'A three component conceptualisation of organisation commitment', Human Resource Management Review, 1(1):61-89.

Meyer, J.P., Allen, N.J. \& Smith, C.A. 1993. 'Commitment to organisations and occupations: Extension of a test of a threecomponent conceptualisation', Journal of Applied Psychology, 78(4):538-551.

Neubert, M., Carlson, D.S., Kacmar, K.M., Roberts, J. \& Chonko, L.B. 2009. 'The virtuous influence of ethical leadership behavior: Evidence from the field', Journal of Business Ethics, 90(2):157170.
Podsakoff, P.M., MacKenzie, S.B., Lee, J.Y. \& Podsakoff, N.P. 2003. 'Common method biases in behavioral research: A critical review of the literature and recommended remedies', Journal of Applied Psychology, 88(5):879-903.

Podsakoff, P.M., MacKenzie, S.B., Paine, J.B. \& Bachrach, D.G. 2000. 'Organisational citizenship behaviours: A critical review of the theoretical and empirical literature and suggestions for future research', Journal of Management, 26(3):513-563.

Podsakoff, P.M., Todor, W.D., Grover, R.A. \& Huber, V.L. 1984. 'Situational moderators of leader reward behavior and punishment behaviors: Fact or fiction?', Organisational Behavior and Human Performance, 34(1):21-63.

Ruiz-Palomino, P., Ruiz-Amaya, C. \& Knörr, H. 2011. 'Employee organisational citizenship behaviour: The direct and indirect impact of ethical leadership', Canadian Journal of Administrative Sciences/Revue Canadienne des Sciences de l'Administration, 28(3):244-258.

Russell, K.A. \& Smith, C.S. 2003. 'Accounting education's role in corporate malfeasance: It's time for a new curriculum', Strategic Finance, 85(6):47-51.

Schwepker Jr, C.H. 2001. 'Ethical climate's relationship to job satisfaction, organisational commitment, and turnover intention in the salesforce', Journal of Business Research, 54(1):39-52.

Stenmark, C.K. \& Mumford, M.D. 2011. 'Situational impacts on leader ethical decision-making', The Leadership Quarterly, 22(5):942-955.

Stevens, B. 1997. 'Hotel ethical codes: A content analysis', International Journal of Hospitality Management, 16(3):261-271.

Tariq, Q. 2012. Former credit manager of hotel gets 12 years for CBT, The Star. June 13, 2012. [online] URL:http://thestar.com.my/news/story.asp?file=/2012/6/13/nation/ $20120613142153 \& \mathrm{sec}=$ nation

The Star Online. (2012a). Bank officer, four others nabbed for credit card forgery, The Star. March 25, 2012. [online] URL:http://thestar.com.my/news/story.asp?file=/2012/3/25/nation/ $20120325161917 \& \mathrm{sec}=$ nation

The Star Online. (2012b). M'sia is ninth most visited in the world in UNWTO list, The Star. February 17, 2012. [online] URL:http://thestar.com.my/news/story.asp?file $=/ 2012 / 2 / 17 /$ nation/ $10752912 \& \mathrm{sec}=$ nation

Treviño, L.K., Brown, M. \& Hartman, L.P. 2003. 'A qualitative investigation of perceived executive ethical leadership: Perceptions from inside and outside the executive suite', Human Relations, 56(1):5-37.

Verschoor, C.C. 2006. 'IFAC committee proposes guidance for achieving ethical behavior', Strategic Finance, 88(6):18-55.

Verschoor, C.C. 2007. 'Who should be blamed the most for the subprime loan scandal?', Strategic Finance, 89(6):11-59.

Walumbwa, F.O., Mayer, D.M., Wang, P., Wang, H., Workman, K. \& Christensen, A.L. 2011. 'Linking ethical leadership to employee performance: The roles of leader,Äìmember exchange, self-efficacy, and organisational identification', Organisational Behavior and Human Decision Processes, 115(2):204-213. 
Williams, L. \& Hazer, J. 1986. 'Antecedents and consequences of satisfaction and commitment in turnover models: A re-analysis using latent variable structural equation models', Journal of Applied Psychology, 71(2):219-231.

Winston, M.D. 2007. 'Ethical leadership and ethical decision making: A meta-analysis of research related to ethics education', Library \& amp; Information Science Research, 29(2):230-251.

Yang, J.-T. 2010.' Antecedents and consequences of job satisfaction in the hotel industry', International Journal of Hospitality Management, 29(4):609-619. 